\title{
Real-time quantitative detection of Vampirovibrio chlorellavorus, an obligate bacterial pathogen of Chlorella sorokiniana
}

\author{
Seth A. Steichen ${ }^{1}$. Judith K. Brown ${ }^{1}$ \\ Received: 1 July 2018 / Revised and accepted: 5 October 2018 / Published online: 25 October 2018 \\ (C) This is a U.S. Government work and not under copyright protection in the U.S.; foreign copyright protection may apply 2018
}

\begin{abstract}
Vampirovibrio chlorellavorus is an obligate, predatory bacterial pathogen of the genus Chlorella. It is recognized as an important pathogen of Chlorella sorokiniana, field isolate DOE 1412, a highly-favored microalga for cultivation in outdoor reactors in the arid USA Southwest for feedstocks used in biofuel production. To determine the $V$. chlorellavorus titer, based on gene copy number, required to cause infection and mortality of $C$. sorokiniana in an experimental outdoor reactor, a multiplexed quantitative polymerase chain reaction (qPCR) assay was developed for pathogen detection, based on the 16S and 18S ribosomal RNA gene of $V$. chlorellavorus and C. sorokiniana, respectively. The assay was further used to establish the optimal effective concentration of benzalkonium chloride required to achieve a below "disease-threshold"-bacterial titer, while minimizing biocidal effects on algal growth and enable economic biomass production. Reactors treated with $2.0 \mathrm{ppm}$ benzalkonium chloride at four-day intervals throughout the cultivation cycle experienced runs of 22 days or longer, compared to 12 days for the untreated control. The qPCR assay was used to estimate disease severity over time using the Area Under the Disease Progress Stairs (AUDPS) metric, indicating a severity rating of 0.016 and 62.308 in biocide-treated and untreated cultures, respectively. The near-real time assay detected as few as 13 copies of $V$. chlorellavorus, allowing for the recognition of its presence in the reactor just before algal cell density decreased, an indication of pathogen attack, while also informing the timing of biocide applications to minimize DOE 1412 infection such that harvestable biomass could be produced.
\end{abstract}

Keywords Biocide $\cdot$ Melainabacteria $\cdot$ Microalgal cultivation $\cdot$ Polymerase chain reaction $\cdot$ Vampirovibrionales

\section{Introduction}

The green microalgae are a polyphyletic group comprised of diverse single-celled eukaryotic organisms that are capable of photosynthesis resulting in the production of oxygen and carbon fixation, despite lacking the structural complexity of the higher land plant taxa (Metting 1996). The cultivation of microalgae as alternate means of producing liquid biofuels has garnered recent interest worldwide. This is due to the propensity of microalgae to multiply rapidly and accumulate as much as $80 \%$ biomass as lipids, and because it is possible to cultivate them on marginal lands otherwise prohibitive to the

Electronic supplementary material The online version of this article (https://doi.org/10.1007/s10811-018-1659-z) contains supplementary material, which is available to authorized users.

\section{Judith K. Brown}

jbrown@ag.arizona.edu

1 School of Plant Sciences, The University of Arizona, Tucson, AZ 85721, USA cultivation of traditional bioethanol crops (Hu et al. 2008). Open-reactor systems are economical platforms for cultivating microalgae (Jorquera et al. 2010). The outdoor cultivation of microalgae presents a number of challenges, including susceptibility to attack by bacterial and viral pathogens and predators. The field isolate of Chlorella sorokiniana (Shihira and Krauss 1965) [Chlorophyta], designated DOE 1412 (Lammers et al. 2017) is considered one of the most promising biofuel production strains, based on a potential maximum growth rate of 5.9 day $^{-1}$ at $36^{\circ} \mathrm{C}$, as determined under a range of simulated temperatures $\left(13-45^{\circ} \mathrm{C}\right)$ analogous to those experienced in arid-land microalgal cultivation locales such as the southwestern USA and other arid climates (Huesemann et al. 2016).

The Regional Algal Feedstock Testbed (RAFT) project was established as a collaborative research project between a team consisting of federal and state university laboratories, with the goal of optimizing outdoor pilot-scale microalgal biomass production for biofuel feedstocks, primarily in locales with arid climates and/or high summer-spring temperatures in the southwestern USA. Algal suspension cultures growing in outdoor 
project reactors maintained throughout the project were monitored for both algae and the phycosphere bacterial community using polymerase chain reaction (PCR) amplification (Saiki et al. 1988) and sequencing of a cloned $1475 \mathrm{bp}$ fragment of the ribosomal RNA small subunit (rRNA SSU) gene to identify microbes influencing biomass production. During April 2014, a BLASTn analysis against rRNA sequences available in the GenBank database indicated the presence of Vampirovibrio chlorellavorus (Gromov and Mamkaeva 1972, 1980) (Park et al. in press), a predatory bacterial pathogen of Chlorella species (Gromov and Mamkaeva 1972; Coder and Goff 1986). This initial detection corresponded with observations of cellclumping and sudden discoloration of $C$. sorokiniana cells, followed by rapid death and complete loss of the cultivation run. These symptoms were consistent with $V$. chlorellavorus effects on Chlorella vulgaris as reported by the first studies on the pathogen, which also found that the bacterium is dimorphic, shifting between vibrioid and coccoid forms of $0.3-0.6 \mu \mathrm{m}$ in diameter, respectively (Gromov and Mamkaeva 1972). Further, it shifts from a motile free-living stage to a larger attached form during the infection cycle (Coder and Goff 1986). A recent phylogenetic analysis has classified V. chlorellavorus in the Cyanobacteria-Melainabacteria group, Phylum Cyanobacteria (https://www.uniprot.org/taxonomy/1117) based on an analysis of 109 single copy gene sequences, with the genera Ca. Caenarcanum, and Ca. Obscuribacter being the closest extant relatives.

An in silico annotation of the first complete genome sequences for the type isolate of $\mathrm{V}$. chlorellavorus identified genes belonging to a type IV secretion system (T4SS), with predicted involvement in attachment of bacterial cells to the cell wall of the Chlorella host (Soo et al. 2015), and is known to translocate host-specific effectors and virulence factors and nutrients across the cell envelope in a large number of bacterial pathogens (Wallden et al. 2010; Voth et al. 2012). These findings are consistent with reported dissolution of cellular contents in V. chlorellavorus-infected algal host cells (Coder and Starr 1978).

To date, no effective management strategies have been developed to abate the damaging effects of $V$. chlorellavorus on cultivated algae. The pathogen is capable of causing nearly $100 \%$ mortality to Chlorella spp. within $24-48 \mathrm{~h}$ after pathogen presence if forewarned, indicated by a sharp decline in $750 \mathrm{~nm}$ optical density (O.D.). However, in a recent study, the duration of the cultivation run was increased substantially by the addition of acid to rapidly decrease the $\mathrm{pH}$ in the reactor from $\mathrm{pH} 7.5$ to 3.5 for $15 \mathrm{~min}$, with restoration to the normal $\mathrm{pH}$ of 7.5 (Ganuza et al. 2016). Such a regime is not practical or environmentally sound for the treatment of large outdoor reactors.

In this study, the quaternary ammonium complex, benzalkonium chloride (BAC), was investigated as a possible treatment for substantially delaying infection of V. chlorellavorus-susceptible Chlorella spp. in outdoor reactors. BAC is a general biocide with known efficacy against a wide range of eubacterial species (Jean et al. 1999; Houari and Di Martino 2007). The antimicrobial mode of action of BAC relies on the amphiphilic character of the molecule that promotes ingression into and disruption of unprotected phospholipid cell membranes (Paulson 2002).

Light microscopic identification of individual bacteria living in mixed communities in outdoor algal production facilities is not straightforward, due to the complexity of most communities and to their small size and variable cell morphologies. In addition, V. chlorellavorus is an obligate pathogen, and so it cannot be established or maintained in pure culture (Coder and Starr 1978; Stewart 2012; Soo et al. 2015). Previous studies have addressed these challenges by the detection of bacteria using fluorescence in situ hybridization (FISH) (Malic et al. 2009) and by end-point polymerase chain reaction (PCR) (Matsuki et al. 1999). However, bacterial titer determination requires a quantitative test that can measure gene copy number, such as real-time, quantitative PCR (qPCR) (Rinttila et al. 2004). In addition, qPCR analysis provides greater specificity and higher sensitivity than conventional PCR detection, enabling detection of target DNA over a range of the concentrations of bacterial cell numbers expected to be encountered throughout an infection cycle.

In this study, an absolute-quantitative PCR assay was developed to facilitate the early detection and to estimate the relative titer, e.g., number of $V$. chlorellavorus cells. The multiplex qPCR assay was designed to target the $16 \mathrm{~S}$ and $18 \mathrm{~S}$ ribosomal RNA small subunit (SSU) gene of $V$. chlorellavorus and C. sorokiniana, respectively, and following the establishment of a standard curve, it was used for monitoring $V$. chlorellavorus in laboratory algal stock cultures and algal-V. chlorellavorus cocultures, and various experimental samples collected from outdoor reactors.

\section{Methods}

\section{Algal culture}

The Chlorella sorokiniana strain DOE 1412, also referred to as NAABB 2412 (Lammers et al. 2017), was isolated from surface water at a collection site in Texas, USA [provided by Dr. J. Polle, Brooklyn College] (Huesemann et al. 2013). The culture was thereafter maintained in the laboratory on BG-11 medium containing $17.6 \mathrm{mM} \mathrm{NaNO}_{3}, 0.22 \mathrm{mM} \mathrm{K}_{2} \mathrm{HPO}_{4}$, $0.03 \mathrm{mM} \mathrm{MgSO} 4 \cdot 7 \mathrm{H}_{2} \mathrm{O}, 0.2 \mathrm{mM} \mathrm{CaCl}{ }_{2} \cdot 2 \mathrm{H}_{2} \mathrm{O}, 0.03 \mathrm{mM}$ citric acid $\cdot \mathrm{H}_{2} \mathrm{O}, 0.02 \mathrm{mM}$ of ammonium ferric citrate, $0.002 \mathrm{mM}$ of $\mathrm{Na}_{2}$ EDTA $2 \mathrm{H}_{2} \mathrm{O}$, and $0.18 \mathrm{mM} \mathrm{Na}_{2} \mathrm{CO}_{3}$, with the addition of trace metals (Rippka and Herdman 1993). Cultures were maintained by periodic serial transfer on solid BG-11 medium containing $30 \mathrm{~g} \mathrm{~L}^{-1}$ of agar. For cultivation, laboratory and outdoor reactor cultures were grown in a 
modified media designed to obtain high yields while minimizing nutrient inputs, referred to as Pecos medium (PE07) (Lammers et al. 2017). The PE07 medium contained $1.7 \mathrm{mM}$ urea $\left(\left(\mathrm{NH}_{2}\right) 2 \mathrm{CO}\right), 0.05 \mathrm{mM} \mathrm{MgSO}{ }_{4} \cdot 7 \mathrm{H}_{2} \mathrm{O}, 0.3 \mathrm{mM}$ $\mathrm{NH}_{4} \mathrm{H}_{2} \mathrm{PO}_{4}, 1.4 \mathrm{mM}$ Potash (KCl), $0.03 \mathrm{mM} \mathrm{FeCl}$, and BG11 trace metal solution. Field experiments were conducted at the University of Arizona outdoor test site ( $+32^{\circ} 16^{\prime} 49.29^{\prime \prime}$, $\left.-110^{\circ} 56^{\prime} 9.82^{\prime \prime}\right)$ in three fresh water reactors, two $762 \mathrm{~L}$ traditional paddlewheel (PW) reactors (Crowe et al. 2012) and one $5600 \mathrm{~L}$ Aquaculture Raceway Integrated Design (ARID) raceway reactor (Waller et al. 2012).

\section{Scanning electron microscopy}

Scanning electron microscopy (SEM) to visualize algal and $V$. chlorellavorus cells from a laboratory co-culture was carried out at the Spectroscopy \& Imaging Facilities (USIF) at the University of Arizona. Clean glass slides were prepared by coating with poly-L-lysine to promote cell adherence prior to being spotted with $200 \mu \mathrm{L}$ live algal cell culture. An equal volume of fixative (4\% paraformaldehyde: $2 \%$ glutaraldehyde $(v / v)$ in $0.2 \mathrm{M}$ sodium phosphate buffer, $\mathrm{pH} 7.4$, was added to each sample, followed by rinsing $3 \times$ in glass deionized water and dehydrated using a standard, ascending ethanol dehydration series of $50-95 \%$ at 10 -min intervals, and a final treatment with $100 \%$ ethanol $(3 \times)$, for $15 \mathrm{~min}$ each, according to the protocol available at https://electron-microscopy.hms. harvard.edu/methods. The specimens were mounted, sputtercoated (Hummer 6 Sputtering Device), and imaged using a Hitachi S-4800 Type II/Thermo NORAN NSS EDS FieldEmission scanning electron microscope.

\section{Total genomic DNA isolation}

Total genomic DNA was isolated from algae culture samples using a cetyltrimethylammonium bromide (CTAB) method modified from previous studies (Doyle and Doyle 1990). Samples were collected in $50 \mathrm{~mL}$ tubes from turbulent sections of outdoor reactors and biomass was sedimented by centrifugation at $4500 \times g$ for $5 \mathrm{~min}$. The supernatant was discarded, and $20 \mathrm{mg}$ of $1.4 \mathrm{~mm}$ stainless steel beads were added to the pellet, together with $1 \mathrm{~mL}$ CTAB buffer containing $20 \mu \mathrm{L} \beta$-mercaptoethanol. The algal cells were disrupted using a Mini-Beadbeater-96 (Bio spec. Products Inc., USA). The supernatant was transferred to a sterile microfuge tube, and an equal volume of chloroform:isoamyl alcohol (24:1) was added and mixed by inverting tubes ten times. The emulsion was broken by centrifugation at $7500 \times g$ for $10 \mathrm{~min}$, and the supernatant was transferred to a microfuge tube and the DNA was precipitated by the addition of $2 / 3 \mathrm{vol}$ of cold isopropanol. After overnight (at least $16 \mathrm{~h}$ ) incubation at $20{ }^{\circ} \mathrm{C}$, DNA was pelleted by centrifugation at $7500 \times g$ for
$10 \mathrm{~min}$. The pellet was washed with $70 \%$ ethanol, air-dried, and dissolved in $20 \mu \mathrm{L}$ Tris-HCl buffer (TE), pH 7.2.

Free living V. chlorellavorus cells in culture medium were separated from those associated with the algal cell biomass by the fractionation of liquid samples. Algal cells and the associated microbes were collected by centrifugation from a $1 \mathrm{~mL}$ sample volume at $7000 \times g$ for $5 \mathrm{~min}$, and the supernatant was transferred to a sterile $1.7-\mathrm{mL}$ microfuge tube. Genomic DNA was isolated from the pelleted biomass as described above. The supernatant was concentrated by vacuum filtration through a sterile $0.2 \mu \mathrm{m}$ Whatman polycarbonate membrane (GE Healthcare, UK). The filter was transferred into a sterile tube and incubated in warm $\left(60^{\circ} \mathrm{C}\right) \mathrm{CTAB}$ buffer for 5 min before $15 \mathrm{~min}$ incubation in a $65{ }^{\circ} \mathrm{C}$ heating block to lyse bacterial cells. The total DNA was isolated using the CTAB method as described.

\section{Ribosomal DNA small sub unit sequencing}

Genomic DNA was isolated from algal biomass samples collected from laboratory DOE 1412 monoculture and open growth reactors at the University of Arizona field site by the method described above and utilized as template for PCR amplification of the algal and bacterial $18 \mathrm{~S}$ and 16S rRNA genes, respectively. The rRNA gene fragments were amplified using the universal 16S rRNA gene primers F16SW/R16SW, described by Weisburg et al. (1991), or the 18S rRNA gene primers, F18S/ R18S (Park et al., unpublished) (Table 1). Standard molecular biology protocols for the recombinant DNA procedures were carried out according to Green and Sambrook (2012). The 16S $(\sim 1.5 \mathrm{~kb})$ and $18 \mathrm{~S}(\sim 1.25 \mathrm{~kb})$ PCR fragments were ligated into pGEM-T Easy plasmid vector (Promega Inc., USA) and transformed into Escherichia coli DH5 $\alpha$ competent cells. Transformed bacterial colonies were selected by blue white screening on agar plates containing X-gal and ampicillin and used as template for PCR of the inserted DNA fragments. The cloned amplicons were subjected to bi-directional DNA sequencing at the University of Arizona Genetics Core (http:// uagc.arl.arizona.edu/) and sequenced on a 3730 DNA Analyzer (Applied Biosystems, USA). Sequences were subjected to the Basic Local Alignment Search Tool (BLAST+) using the NCBI GenBank nr database to assign provisional identification based on similarity score (Camacho et al. 2009; Benson et al. 2013). A single representative $16 \mathrm{~S}$ or $18 \mathrm{~S}$ rRNA gene sequence was submitted to the NCBI GenBank database and assigned the accession no. KM068038 for C. sorokiniana strain DOE 1412, and KP710184 for V. chlorellavorus.

\section{Quantitative PCR assay design and analysis}

The $16 \mathrm{~S}$ or $18 \mathrm{~S}$ rRNA gene sequences were used as templates for the design of the primers and hydrolysis probe sets for each target organism. The primers were designed using the 
Table 1 Primer and probe sequences for quantitative polymerase chain reaction amplification

\begin{tabular}{llll}
\hline $\begin{array}{l}\text { Primer/probe } \\
\text { name }\end{array}$ & Sequence $^{\mathrm{a}}\left(5^{\prime}\right.$-3' $^{\prime}$ & Amplification type & Reference \\
\hline F16SW & AGAGTTTGATCMTGGCTCAG & PCR & Weisburg et al. 1991 \\
R16SW & ACGGTTACCTTGTTACGACTT & PCR & Weisburg et al. 1991 \\
F18S & GGGTTCGATTCCGGAGAG & PCR & Park et al. unpublished \\
R18S & GTACAAAGGGCAGGGACGTAAT & PCR & Park et al. unpublished \\
qVV_F & CTTACCTGGGCTTGACATCTAC & PCR/qPCR & This study \\
qVV_R & TAACCCAACATCTCACGACAC & PCR/qPCR & This study \\
qVV_P & /6-FAM/TAAGACAGG/ZEN/TGGTGC ACGGTTGTC/3IABkFQ/ & PCR/qPCR & This study \\
D18S_F & GGTCCAGACATAGTGAGGATTG & PCR/qPCR & This study \\
D18S_R & CTCGTTCGTTACCGGAATCA & PCR/qPCR & This study \\
D18S_P & /56-JOEN/TAGTTGGTG/ZEN/GGTTGC CTTGTCAGG/3IABkFQ/ & PCR/qPCR & This study \\
\hline
\end{tabular}

${ }^{\text {a }}$ Probe modifications indicated within sequences as FAM or JOEN dyes and ZEN or 3IABkFQ (Iowa Black FQ) quenchers (Integrated DNA Technologies, USA)

PrimerQuest Tool available at the Integrated DNA Technologies, USA website, https://www.idtdna.com/PrimerQuest/. Primer selection was based on the guidelines provided with respect to amplicon size, GC content, and secondary structure (Taylor et al. 2010). Secondary structure and other primer parameters were checked by use of the Primer3 algorithm (Rozen and Skaletsky 2000). The specificity of $V$. chlorellavorus $16 \mathrm{~S}$ primers/probe was assessed by both the Ribosomal Database Project (RDP) Probe Match tool (Cole et al. 2005) and the SILVA TestPrime 1.0 tool (Klindworth et al. 2013). An alignment of closely related green algae species was used to determine the specificity of the C. sorokiniana primers and probe.

The qPCR analysis was performed using a StepOnePlus Real Time PCR system (Applied Biosystems, USA) where reactions were arranged in 96 well plates. Detection of the bacterial 16S rRNA gene and algal 18S rRNA gene were multiplexed into single $25-\mu \mathrm{L}$ reactions containing $12.5 \mu \mathrm{L}$ TaqMan Universal PCR Master Mix, $1.25 \mu \mathrm{L}$ of each qVV_F/ $\mathrm{R}$ and D18S_F/R primer pair $(10 \mu \mathrm{M}), 0.625 \mu \mathrm{L}$ of qVV_P and D18S_P probes, and $7.75 \mu \mathrm{L}$ of nuclease-free water. The cycling parameters were executed as follows: $50{ }^{\circ} \mathrm{C}$ for $2 \mathrm{~min}$, $95^{\circ} \mathrm{C}$ for $10 \mathrm{~min}, 40$ cycles at $95^{\circ} \mathrm{C}$ for $10 \mathrm{~s}$, and a final step of $58.8^{\circ} \mathrm{C}$ for $60 \mathrm{~s}$. The reactions were carried out in triplicate. The limit of detection (LOD), blank (LOB), and quantification (LOQ) were calculated using the equations, $\mathrm{LOD}=\mathrm{e}^{\frac{38-B_{S C}}{M_{S C}}}$, $\mathrm{LOB}=$ mean $_{\text {blank }}-\left(1.645 \times \mathrm{SD}_{\text {blank }}\right)$ and $\mathrm{LOQ}=\operatorname{mean}_{L O B}+$ $\left(3 \times \mathrm{SD}_{L O B}\right)$, where $B_{S C}$ and $M_{S C}$ indicate the intercept and slope of the standard curve, and SD is the standard deviation (Armbruster and Pry 2008).

\section{Standard curve}

The plasmid vectors (pGEM T-Easy) (Promega, USA) harboring the expected size fragment of $1475 \mathrm{bp}$ and $1238 \mathrm{bp}$ for the
$16 \mathrm{~S}$ and 18S rRNA gene, respectively, were used in conventional PCR to amplify the qPCR target fragments, followed by molecular cloning and DNA sequencing to verify amplicon fidelity. The primer pairs, qVV F/qVV R and D18S F/ D18S R, were used to amplify a fragment of the expected size for V. chlorellavorus (113 bp) and DOE 1412 (119 bp) template DNA, respectively. The amplicons were ligated into pGEM-T Easy plasmid vector and used to transform $E$. coli DH $5 \alpha$ cells. The bacterial cells were incubated overnight $(16 \mathrm{~h})$ in LB medium and plasmid was purified from cultures using GeneJET plasmid miniprep Kits (Thermo Scientific, USA). Because previous studies indicate the over estimation of copy number with circular plasmid standards (Hou et al. 2010), each plasmid was linearized by enzyme digestion with PstI (New England Biolabs, USA) before quantification by spectrophotometer (NanoDrop 2000, ThermoScientific, USA). The plasmid copy number (NCP; copies $\mu \mathrm{L}^{-1}$ ) was calculated as: $\mathrm{NCP}=\left(\mathrm{PC} \times 10^{-9} \times 6.02 \times 10^{23}\right) \div(N \times 660)$, where $\mathrm{PC}$ is the concentration of plasmid $\left(\mathrm{ng} \mu \mathrm{L}^{-1}\right)$ and $N$ represents the number of bases for the recombinant plasmid. Tenfold dilutions of the plasmid vector containing the target rRNA gene fragment in deionized water were used as template to establish the standard curve.

\section{C. sorokiniana SSU rRNA gene copy number determination}

Samples of the algal suspension cells were collected from a monoculture of DOE 1412 in exponential growth phase. Deionized water was used to make a series of six fivefold dilutions of the sample. The density of each dilution sample was measured by absorbance at $750 \mathrm{~nm}$ and by cell counts, using bright-field (BR) and/or fluorescent (FL) illumination available in the Cellometer Vision (Nexcelom Biosciences, USA) automated imaging system. Samples were measured 
Fig. 1 Scanning electron micrograph of clumped Chlorella sorokiniana, DOE 1412, cells infected with Vampirovibrio chlorellavorus at a $5000 \times$ magnification and b $10,000 \times$ magnification with putative V. chlorellavorus cells marked by black arrows and conjugal transfer tube indicated by a white arrow
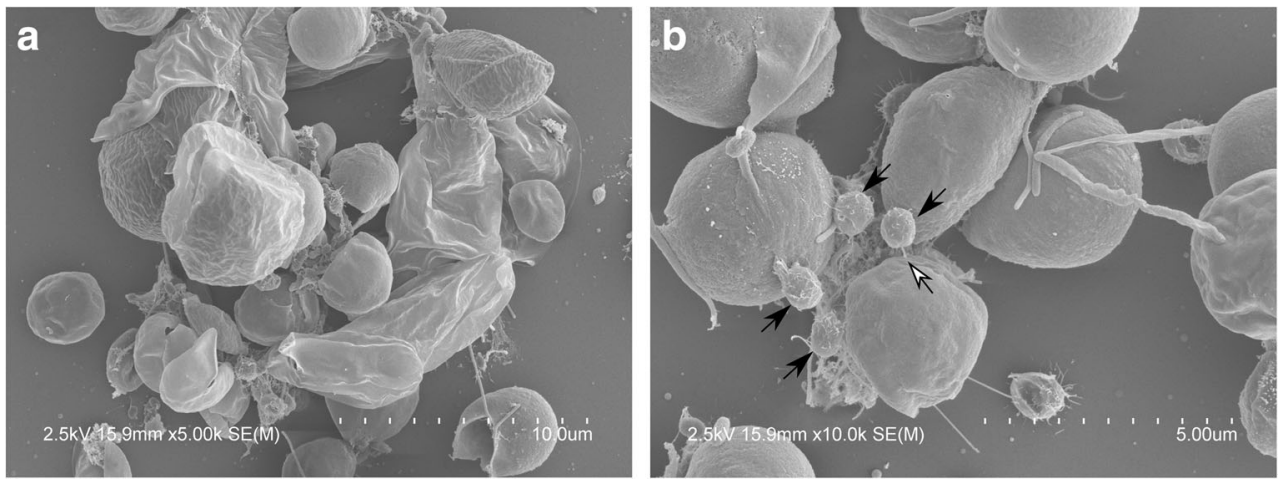

in triplicate for each dilution of the algal suspension cells. Total DNA was isolated using the CTAB method of Doyle and Doyle (1990). The number of 18S rRNA gene copies per cell was estimated by plotting the copy number as a function of BR/FL cell count.

\section{Benzalkonium chloride biocide treatment}

A gradient of BAC concentrations between 0.0 and $1.5 \mathrm{ppm}$ were tested by laboratory experiments on $50-\mathrm{mL}$ flask cultures containing DOE 1412 and field collections of V. chlorellavorus. Preliminary results indicated that higher BAC concentration reduced rate of $V$. chlorellavorus accumulation, prolonged algal culture, and did not have a discernable effect on exponential algal growth rate (data not shown). To test the effects of BAC on $V$. chlorellavorus infection of algae grown in outdoor reactors, experiments were conducted in two identical and collocated PW oval shaped reactors (PW1 and PW2). Reactors were inoculated with laboratory grown DOE 1412 cells at an optical density of 0.2 (OD750), equivalent of between $3 \times 10^{6}$ and $5 \times 10^{6}$ cells $\mathrm{mL}^{-1}$, in PE07 medium. Collected biomass was maximized by harvesting $75 \%$ of culture volume during exponential algal growth $(\mathrm{OD} 750 \geq 1.5)$, followed immediately by replenishment of water and $1 \times$ equivalent media nutrients. Cultures were scored as dying upon observed decrease in algal cell density over two consecutive days. One PW unit was treated with a dose of $2.0 \mathrm{ppm}$ benzalkonium chloride every fourth day during growth with the other left as an untreated control. Drop samples were processed from each reactor every 2 days for qPCR assessment of $V$. chlorellavorus. Biomass productivity was determined based on the ash free dry weight (AFDW) used to calculate the areal productivity by subtracting biomass
Table 2 Summary of in silico analysis of $V$. chlorellavorus primers and probe specificity among SILVA database $16 \mathrm{~S}$ rRNA gene sequence accessions

\begin{tabular}{lrrrrr}
\hline Taxonomy $^{\mathrm{a}}$ & qVV_FR match $^{\mathrm{b}}$ & $\mathrm{qVV}_{-}$match $^{\mathrm{b}}$ & $\begin{array}{l}\text { qVV_FR } \\
\text { coverage }^{\mathrm{c}}\end{array}$ & $\begin{array}{l}\mathrm{qVV}_{\text {qPage }} \\
\text { coverage }^{\mathrm{c}}\end{array}$ & $\begin{array}{l}\text { Total 16S } \\
\text { rRNA gene } \\
\text { accessions }\end{array}$ \\
\hline SILVA NR & 184 & 135 & 0.0 & 0.0 & 576,050 \\
Bacteria & 184 & 135 & 0.0 & 0.0 & 500,102 \\
Bacteroidetes & 1 & 1 & 0.0 & 0.0 & 48,881 \\
Cyanobacteria & 20 & 131 & 0.2 & 1.2 & 10,942 \\
Melainabacteria & 19 & 131 & 3.8 & 25.9 & 505 \\
Vampirovibrionales & 19 & 31 & 30.6 & 50 & 62 \\
Firmicutes & 2 & 2 & 0.0 & 0.0 & 133,580 \\
Clostridia & 2 & 2 & 0.0 & 0.0 & 82,353 \\
Clostridiales & 2 & 2 & 0.0 & 0.0 & 80,923 \\
Ruminococcaceae & 1 & 1 & 0.0 & 0.0 & 22,570 \\
Ruminococcaceae UCG-013 & 1 & 1 & 0.3 & 0.3 & 345 \\
Proteobacteria & 142 & 1 & 0.1 & 0.0 & 193,964 \\
Deltaproteobacteria & 133 & 1 & 0.9 & 0.0 & 15,112 \\
GR-WP33-30 & 1 & 0.1 & 0.1 & 728 \\
\hline
\end{tabular}

${ }^{\text {a }}$ SILVA taxonomic designations are listed in descending rank. Phyla are indicated by bold text with lower ranks italicized

${ }^{\mathrm{b}}$ Indicates the number of sequences matching the oligonucleotides in each respective taxonomic rank

${ }^{\mathrm{c}}$ Indicates the percentage of matches to primer and probe sequences for each taxonomic rank within the SILVA database 


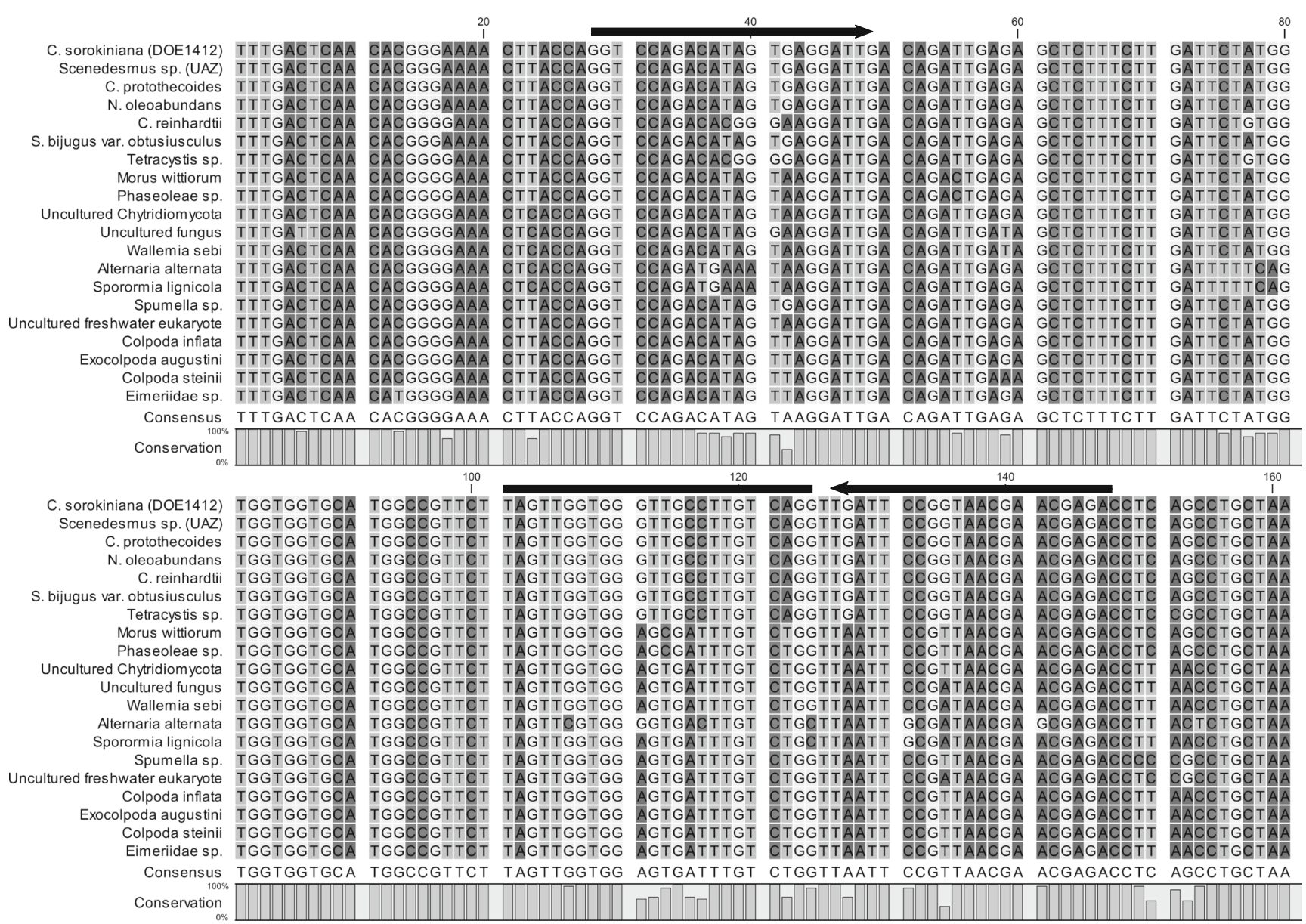

Fig. 2 Alignment of the partial 18S rRNA gene sequence (183 bp) of seven microalgae strains, and 13 eukaryotic organisms identified in the field site open pond reactors and the surrounding area. The Chlorella

concentration $\left(\mathrm{g} \mathrm{L}^{-1}\right)$ from that of the previous time point, multiplied by the reactor volume, and divided by the surface area and the number of days from the last AFDW measurement, expressed as $\mathrm{g} \mathrm{m}^{-2}$ day $^{-1}$ (Pedroni et al. 2004). To reduce bias against the declining biomass in the final days of untreated cultures, average productivity was based only on exponential growth phases of each run. Calculations of disease severity were made by finding the relative Area Under Disease Curve Stairs (rAUDPS) (Simko and Piepho 2012), herein based on the accumulation of $V$. chlorellavorus rRNA gene copies, as the 16S:18S ratio over time, implemented in the agricolae package in R (R Core Team 2013; De De Mendiburu 2014).

\section{Results}

\section{Scanning electron microscopy}

The presence of $V$. chlorellavorus in DOE 1412 culture was observed by scanning electron microscopy to complement molecular identification. The micrographs generated from sorokiniana (DOE 1412) primers and probe D18S_F, D18S_R, and D18S_P complementation sites are indicated by the black forward arrow, reverse arrow, and bar, respectively

outdoor C. sorokiniana monoculture samples indicated the presence of bacterial cells with diameters between $\sim 0.8$ and $1.2 \mu \mathrm{m}$ in close association with algal cells (Fig. 1). The higher magnification image revealed an intricate ultrastructure consisting of fine hair-like protrusions covering the bacterial cells. Also, both intact and lysed algal cells were present.

\section{Primer-probe specificity}

The gene encoding 16s rRNA has proven to be effective for culture-independent identification of prokaryotes in part because of its high degree of conservation across all known species (Amann et al. 1995). This feature also makes careful selection of the primer and probe annealing sites in more variable regions of the sequence crucial for specificity (Marchesi

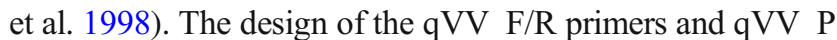
probe was evaluated for specificity against the SILVA NR 16S rRNA gene database by searching for accessions that matched all three oligonucleotide sequences (Table 2). The nonredundant database consists of 576,050 unique 16S rRNA gene sequences, of which qVV_F/R and qVV_P, matched 
184 and 135 accessions, respectively. Among the accessions that matched both the primers and probe, 19 were classified in the Vampirovibrionales, the order that contains V. chlorellavorus (Soo et al. 2014). Within the SILVA NR database, one accession each within the phyla Firmicutes (uncultured Clostridiaceae bacterium; AB089024) and Proteobacteria (uncultured Desulfovibrio bacterium; AY214186) matched the primers and the probe sequences, indicating that $\sim 0.0003 \%$ of predicted off-target sequences might be detected by the qPCR assay (Table 2).

A second set of primers and probe that targeted the algal host 18S rRNA gene was used in the multiplex reactions for normalization of bacterial 16S rRNA gene copies in relation to the amount of host DNA in a sample (Duffy et al. 2013). The D18S_F/R and D18S_P sequences are homologous to the C. sorokiniana $18 \mathrm{~S}$ rRNA gene, as well as several other chlorophytic green microalgae species (Fig. 2). Previous analysis of $18 \mathrm{~S}$ rRNA gene sequences in the ARID outdoor PW and ARID reactors (2014-2016), and of algal composition in soil samples taken from a nearby riverbed (2014-2015) (considered a possible source of competitor algae and/or of algal pathogenic bacteria), showed that samples contained an abundance of algae and other eukaryotic organisms (Park et al. in press). The $18 \mathrm{~S}$ rRNA gene sequence determined for the nonC. sorokiniana eukaryotic organisms in the reactor phycosphere and the $C$. sorokiniana $18 \mathrm{~S}$ rRNA gene sequences were analyzed using a multiple sequence alignment, with a gap open cost of 10.0 and a gap extension cost of 1.0 as implemented in CLC sequence viewer 7.7, to determine sequence conservation at the D18S_F/R and D18S_P annealing sites (Fig. 2).

\section{Standard curve}

The standard curves for the $16 \mathrm{~S}$ and 18s rRNA gene qPCR targets were drawn by calculating the linear relationship between their respective $\mathrm{C}_{\mathrm{q}}$ values and the denary logarithms of plasmid copy numbers (Fig. 3). The two curves were determined using a tenfold dilution series consisting of the plasmid containing the cloned insert ranging from $10^{4}$ to $10^{11}$ copies per microliter used as template. Linear regression of the data yielded the following equations for $V$. chlorellavorus $16 \mathrm{~S}$ and C. sorokiniana $18 \mathrm{~S}$ rRNA gene assays respectively; $y=-$ $4.1 x+50, r^{2}=0.997$ and $y=-3.9 x+57, r^{2}=0.992$. The sensitivity of each assay was determined by calculating the LOD, LOB, and LOQ, compared to nuclease-free water blanks $(n=40)$, indicating that the bacterial and algal rRNA gene could be detected at greater than 19 and 131 copies, respectively, with $95 \%$ confidence (Table 3).

\section{Copy number of the $18 \mathrm{~S}$ rRNA gene}

Picoeukaryotic organisms encode different numbers of $18 \mathrm{~S}$ SSU rRNA genes, defined as "copy number", ranging from
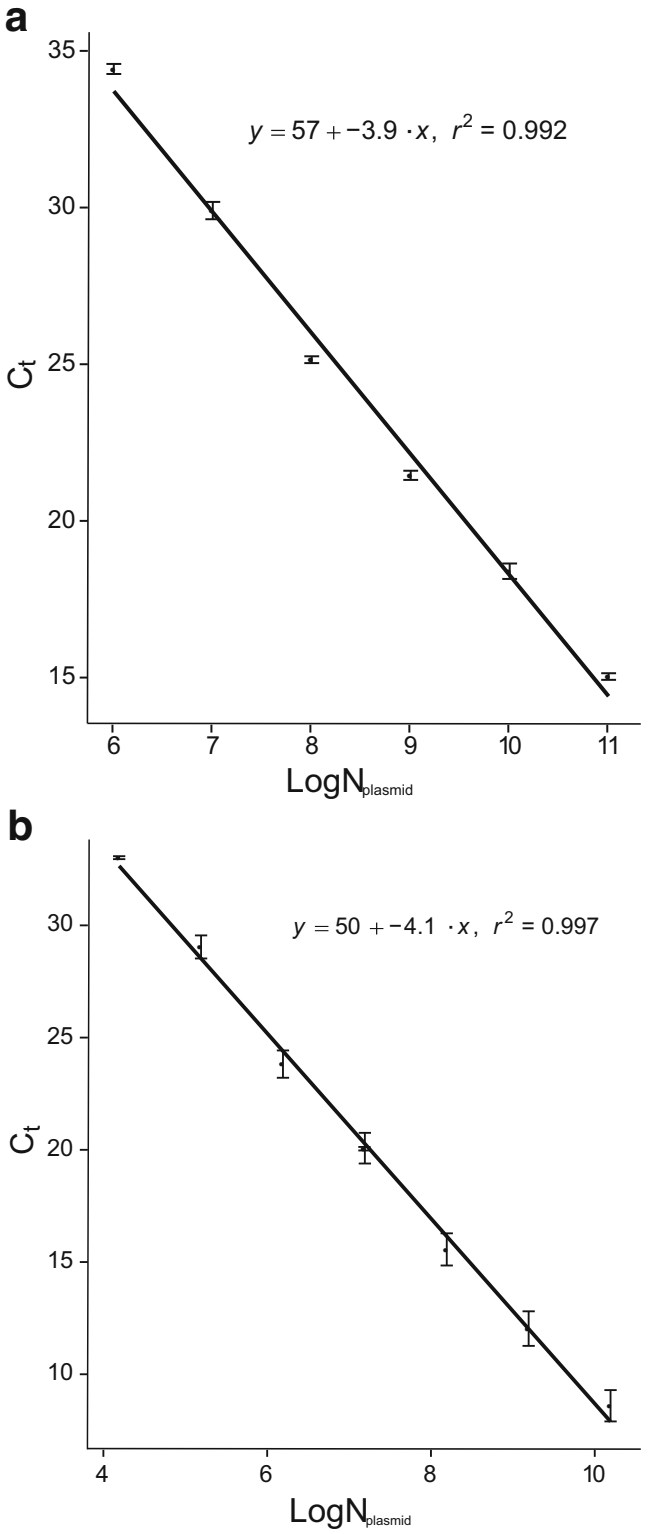

Fig. 3 Results of five replicated standard curve experiments, reported as cycle threshold $(\mathrm{Ct})$ response to molecular mass quantified plasmids bearing both the a Chlorella sorokiniana $18 \mathrm{~S}$ ribosomal RNA gene sequence and b Vampirovibrio chlorellavorus 16S ribosomal RNA gene sequence. Plasmid copy numbers are represented in log base 10. Error bars indicate \pm standard deviation $n=5$

Table 3 Statistical limits of quantitative polymerase chain reaction assays

\begin{tabular}{llcc}
\hline Target & $\begin{array}{l}\text { Limit of } \\
\text { detection }\end{array}$ & Limit of blank & $\begin{array}{l}\text { Limit of } \\
\text { quantification }\end{array}$ \\
\hline V. chlorellavorus & 12.67 & 9.87 & 18.67 \\
C. sorokiniana & 97.68 & 56.34 & 130.56 \\
\hline
\end{tabular}

${ }^{\mathrm{a}}$ The limit calculations are reported in units of $16 \mathrm{~S}$ and 18S rRNA gene copy number 


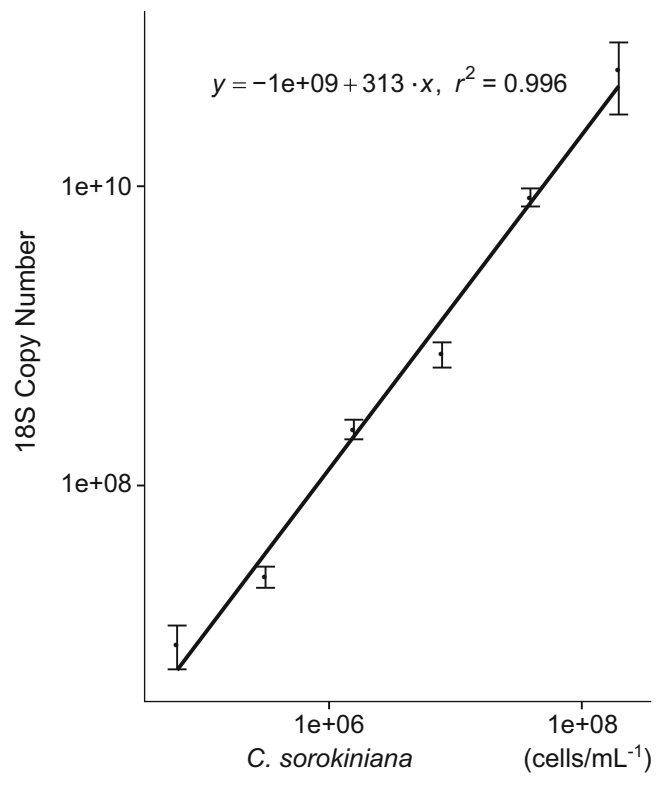

Fig. 4 The number of copies of 18S rRNA gene for a laboratorymaintained monoculture of Chlorella sorokiniana cells, calculated using the standard curve equation (Fig. 3A) and number of counted cells in a tenfold dilution series of algae monoculture. The linear regression line is displayed. The corresponding equation and the $r^{2}$ goodness of fit are indicated. The error bars represent \pm standard deviation of biological replicates $n=3$

one copy in some organisms, to as many as 12,000 in the large dinoflagellate, Akashiwo sanguinea (K. Hirasaka) G. Hansen \& Moestrup (Daugbjerg et al. 2000) (Zhu et al. 2005). The relationship between the $18 \mathrm{~S}$ rRNA gene copy number and DOE 1412 cell counts was determined for algal cultures at

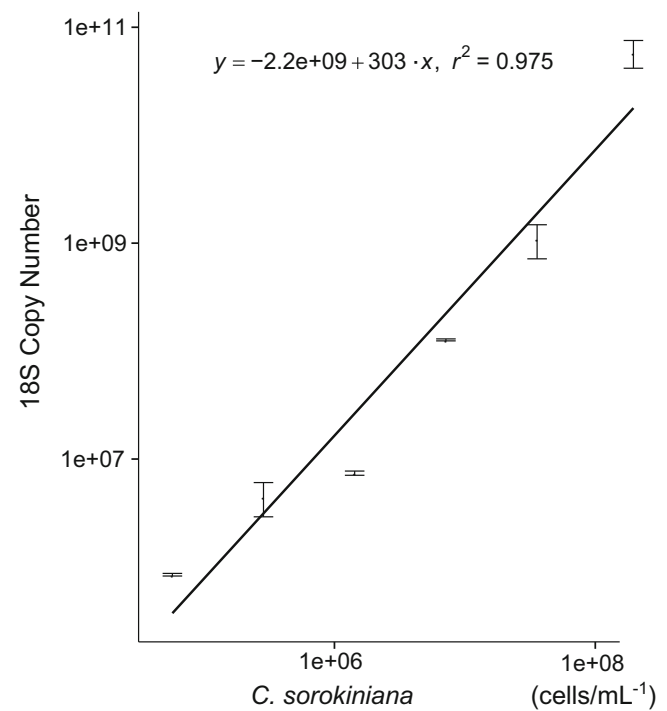

Fig. 5 The number of copies of 18S rRNA gene for a monoculture of Chlorella sorokiniana cells grown in outdoor reactors, calculated using the standard curve equation (Fig. 3A) and number of counted cells in a tenfold dilution series of algae monoculture. The linear regression line is displayed. The corresponding equation and the $r^{2}$ goodness of fit are indicated. The error bars represent \pm standard deviation of biological replicates $n=3$
Fig. 6 Benzalkonium chloride effects on DOE 1412 growth and Vampirovibrio chlorellavorus accumulation in field reactors. Growth data of experiments conducted from a Aug 30 to Sept 22, b Sept 23 to Oct 12, and $\mathbf{c}$ Oct 4 to Oct 30, 2016 reporting Top) culture temperature is displayed as recorded by continuous data logger from PW1 reactor unit and compared across a time course of 25 days of growth against Middle) the optical density (absorbance at $750 \mathrm{~nm}$ ) of Chlorella sorokiniana culture in collocated PW reactor units either treated with BAC or a no treatment control (NT) as well as rain fill, quantified by the volume of water added to reactors. Bottom) V. chlorellavorus accumulation is displayed in both biomass and supernatant fractions by the ratio of $16 \mathrm{~S}$ ribosomal RNA gene per algal cell 18S ribosomal RNA gene detected on a logarithmic scale which excludes initial time point samples of undetected 16S ribosomal RNA genes

densities between $10^{4}$ and $10^{8}$ cells $\mathrm{mL}^{-1}$ (Fig. 4). Over 300 gene copies per genome were inferred based on the slope of the linear regression equation. When applied to the qPCR assay results, this information allowed the $V$. chlorellavorus $16 \mathrm{~S}$ rRNA gene copy number to be related to algal cell ]number, defining the $V$. chlorellavorus Disease Ratio (VDR) for each time period measured using the equation: $V D R=\frac{16 S \text { rDNA copy } \#}{18 S \text { rDNA copy }} \times 313$. An analysis of the DOE 1412 algal cultures growing in the outdoor reactor, indicated a copy number for C. sorokiniana of 303 copies per cell (Fig. 5).

\section{Biocide treatment effects on outdoor DOE 1412 biomass production}

The "severity" of $V$. chlorellavorus infection was reduced in BAC-treated outdoor paddlewheel (PW) reactors compared to the untreated PW reactors, based on measurements of VDR at regular time intervals during the growth cycle. Water samples were collected from BAC-treated and -untreated PW reactors at intervals of 2 days for runs ranging in duration from 10 to 26 days, and for three independent growth cycles. Each reactor was inoculated with cultures using standard procedures, and one reactor was treated with $2.0 \mathrm{ppm} \mathrm{BAC}$, while the other was untreated, referred to hereafter, as the non-treated (NT) control. The results from these experiments indicated that the pathogen could be detected and quantified over the course of the cultivation cycle, and that based on qPCR results, the BAC-treated algal cultures harbored lower levels of the $V$. chlorellavorus pathogen, compared to the NT controls (Fig. 6). The algal cultivation runs in the BAC treated reactors showed increased average longevity, at 22 days, compared to the NT control reactors, for which the duration of the culture was only 12 days. This extension of the growth cycle resulted in higher biomass productivity in the treated over untreated reactors, at 55.5 to $61.2 \%$, despite the decrease in average biomass accumulation rate that resulted from the BAC biocide treatment, during the exponential growth phase for test runs: $18,23,25$, and 27 , at $14.2,32.8,6.08$, and $12.1 \%$, respectively (Table 4). 

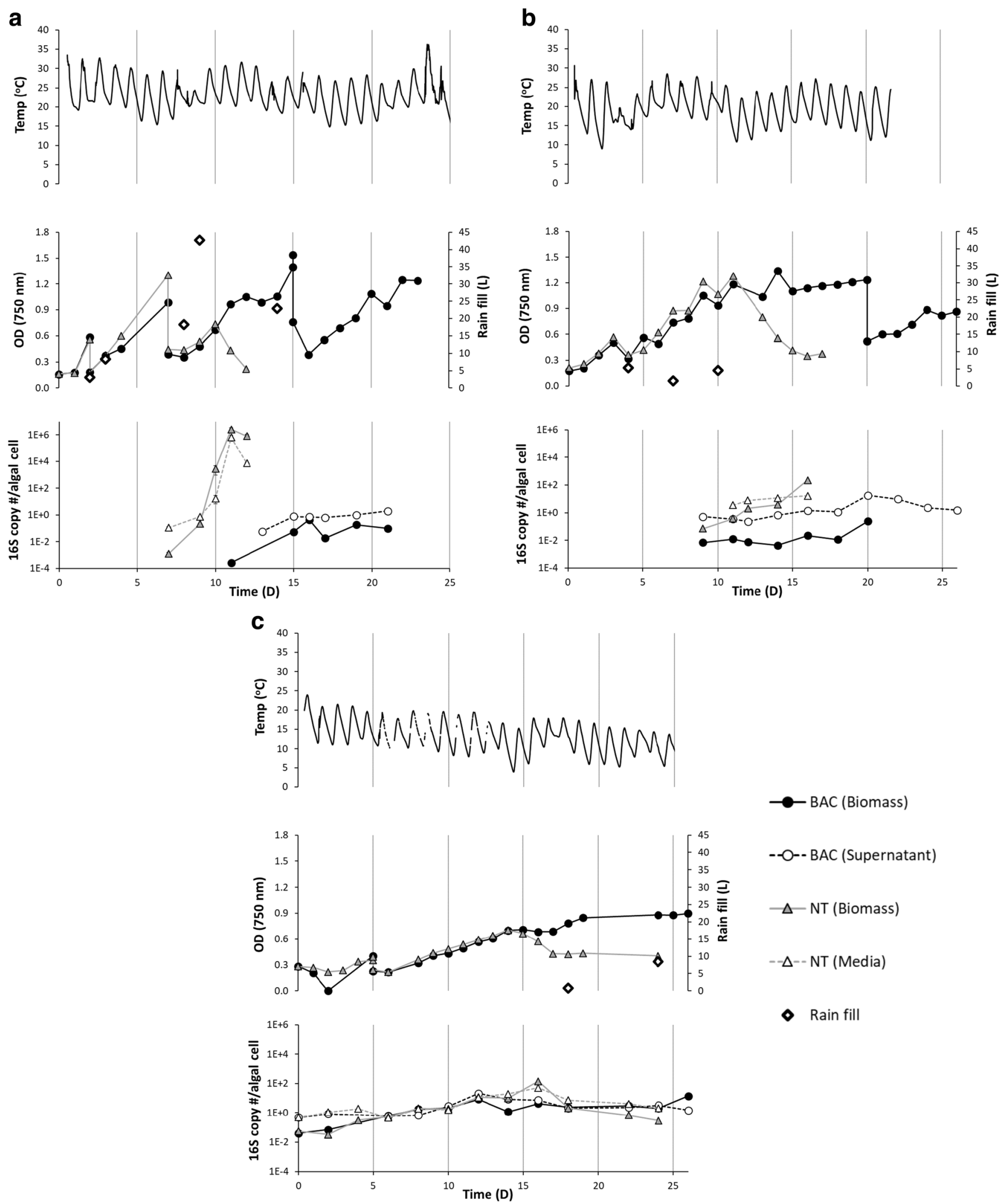

To quantify "disease severity" resulting from pathogen attack of C. sorokiniana DOE 1412 during successive cultivation cycles, the total VDR was estimated for each experimental culture using a calculation that determines the relative Area
Under Disease Progress Stairs (rAUDPS) (Simko and Piepho 2012). This approach has been used to estimate severity for diseases that yield irregular disease curves and lack wellfitting models, to normalize each round of a disease scenario 
Table 4 Productivity of C. sorokiniana monocultures grown in outdoor reactors treated with benzalkonium chloride (BAC) or not treated (NT)

\begin{tabular}{llllll}
\hline RAFT run $^{\mathrm{a}}$ & Bioreactor & Treatment & $\begin{array}{l}\text { Average exponential } \\
\text { biomass productivity } \\
\left(\mathrm{g} \cdot \mathrm{m}^{-2} \cdot \text { day }^{-1}\right)\end{array}$ & Duration (d) & $\begin{array}{l}\text { Total biomass } \\
\text { productivity }\left(\mathrm{g} \mathrm{m}^{-2}\right)\end{array}$ \\
\hline 18 & PW2 & BAC & 12.40 & 20 & 292.35 \\
18 & PW1 & NT & 14.46 & 13 & 187.97 \\
23 & PW1 & BAC & 7.86 & 24 & 188.68 \\
23 & PW2 & NT & 11.70 & 10 & 117.02 \\
25 & PW1 & BAC & 6.33 & 19 & 120.19 \\
25 & PW2 & NT & 6.74 & 11 & 74.09 \\
27 & PW1 & BAC & 2.82 & 26 & 73.32 \\
27 & PW2 & NT & 3.12 & 14 & 43.68 \\
\hline
\end{tabular}

${ }^{\text {a }}$ Matched RAFT run numbers indicate cultures grown during the same time period by dividing by duration of the growth of the host, in relation to the time of the onset of initial infection (Fry 1978). These calculations revealed very large inter-run differences in disease severity, indicating that the NT cultures experienced between one to as great as seven orders of magnitude disease severity than the paired BAC treated counterparts (Table 5). The average rAUDPS for the NT reactors $(n=4)$ was 62.308 , a value that was greater than that for BAC-treated reactors $(n=4)$, for which the average was 0.016 , irrespective of the somewhat variable environmental conditions experienced throughout the summer and fall months that are most optimal for DOE 1412 cultivation at the ARID site.

\section{Discussion}

The development of a qPCR assay for monitoring the presence and accumulation of $V$. chlorellavorus cells in $C$. sorokiniana microalgae culture provided an essential molecular diagnostic tool to inform the timing of mitigation activities and reduce the deleterious effects of the pathogen on algal cultivation in the ARID-outdoor reactors. The qPCR assay was shown to be sensitive, allowing for the detection of 13 copies of $V$. chlorellavorus per milliliter of sampled water, and results could be made available within $6 \mathrm{~h}$ from the time of sampling.
This rapid turn-around time allowed for decision-making to either treat the pathogen-affected reactor(s), or harvest the algal biomass sooner than planned so that at least some of the biomass could be salvaged (McBride et al. 2014).

The 18S rRNA gene copy per $C$. sorokiniana DOE 1412 cell (size 5-7 $\mu \mathrm{m}$ ) estimated herein is in agreement with previously determined values for Chlamydomonas concordia cell $(\sim 7 \mu \mathrm{m})$, which is estimated to encode 300-400 18S rRNA gene copies, and shows a good fit based on the positive linear correlation between cell size and 18S copy number (Zhu et al. 2005). Also, the estimated copy number of 16S rRNA gene encoded by an individual $C$. sorokiniana cell, at 313 , and one bacterial cell, per copy of 16S rRNA gene, was consistent for laboratory and field samples, indicating that the $V$. chlorellavorus Disease Ratio (VDR) calculation provided a useful estimate of the relative pathogen load, regardless of the origin of the sample source.

Plant epidemiological studies have stressed the importance of using "quantitative, accurate, and unbiased methods" that enhance predictive power over that available from less stringent approaches (Lindow 1983). The use of the 18S rRNA gene as the target for the detection and quantification of $C$. sorokiniana for qPCR amplification provided reproducible results, reduced the requirement for extracting DNA isolation efficiency between samples. Establishing a useful metric for quantifying disease severity requires measurement of disease progress as a
Table 5 Disease severity estimates for C. sorokiniana DOE 1412 monocultures grown in or reactors treated with benzalkonium chloride (BAC) or not treated (NT)

\begin{tabular}{lllll}
\hline RAFT run & Bioreactor & Treatment & $\begin{array}{l}\text { Biomass normalized } \\
\text { RelAUDPS }^{\mathrm{a}}\end{array}$ & $\begin{array}{l}\text { Supernatant normalized } \\
\text { RelAUDPS }^{\mathrm{a}}\end{array}$ \\
\hline 18 & PW2 & BAC & $3.22 \mathrm{E}-02$ & N/A \\
18 & PW1 & NT & $1.01 \mathrm{E}-01$ & N/A \\
23 & PW1 & BAC & $2.01 \mathrm{E}-05$ & $1.62 \mathrm{E}-04$ \\
23 & PW2 & NT & $2.49 \mathrm{E}+02$ & $4.81 \mathrm{E}+01$ \\
25 & PW1 & BAC & $3.14 \mathrm{E}-06$ & $2.23 \mathrm{E}-04$ \\
25 & PW2 & NT & $2.35 \mathrm{E}-04$ & $3.89 \mathrm{E}-03$ \\
27 & PW1 & BAC & $3.02 \mathrm{E}-02$ & $3.82 \mathrm{E}-02$ \\
27 & PW2 & NT & $1.32 \mathrm{E}-01$ & $8.47 \mathrm{E}-02$ \\
\hline
\end{tabular}

${ }^{\text {a }}$ Relative area under disease progress stairs calculations are normalized by growth duration 
proportion of host tissues affected in the "diseased state". Here, this was estimated with an apparently high degree of accuracy because it was possible to incorporate the detection of a molecular marker for both the host and pathogen in the same qPCR reaction. While this approach enabled disease severity ratings to be monitored at individual, regular time points, the AUDPS calculations permitted the integration of severity ratings over the entire growth cycle. It further allowed for the direct comparison of severity of disease, e.g., relative magnitude of the effects of infection, for BAC-treated and -untreated reactors, with the untreated algae cultures showing 3894-fold greater average rAUDPS, calculated by dividing the average NT measures of 62.308 by the BAC average of 0.016 . The estimation of disease severity and disease progression using the AUDPS approach could readily be integrated as a viable tool for algal crop management, particularly when comparing management strategies, and for extrapolating the results to predicting the likelihood of outbreaks under different environmental conditions, based on the optimal growth conditions determined for different algal species and environmental constraints.

The reduction of disease severity in BAC-treated cultures contributed to the prolonged algal growth in the ARID reactors. This outcome is similar to that achieved by the low-pH treatment reported previously (Ganuza et al. 2016); however, the use of BAC avoids exposure to strong acid, and for outdoor reactors is potentially less harmful to the environment. Because BAC is a general biocide, there is a tradeoff between its efficacy to abate pathogen attack by reducing the rate at which V. chlorellavorus accumulated in the reactors, and the negative effect of the biocide on algal growth. Balancing these two aspects is critical for producing an economical algal crop (Amer et al. 2011). The growth rate of treated C. sorokiniana in the field reactors, as measured by optical density, was reduced by an average of $\sim 16.3 \%$ relative to the untreated cultures. While this reduction may have been due to the direct biocidal effects of BAC on algal growth, it may have also caused harmful effects to the microbial community in the phycosphere, through premature death or direct mortality, perhaps also slowing the growth of mutualistic bacteria.

The results presented here for three independent C. sorokiniana ARID growth cycles provide insights into certain factors that may determine certain dynamics of algal host$V$. chlorellavorus pathogen interactions. For example, rainfall has been shown to be a factor in the loss of productivity and rapidly declining cell numbers, followed by mortality of ARIDcultivated $C$. sorokiniana. Here, the highest recorded accumulation of $V$. chlorellavorus biomass in the outdoor reactors $(2.56 \times$ $10^{6} \mathrm{VDR}$ ) was found to be directly preceded by rainfall that in one storm, contributed $42.7 \mathrm{~L}$ of water to the open reactors during the cultivation period (Fig. 6A). This is thought to have resulted in inoculation of the algal reactors with aerosols containing $V$. chlorellavorus cells, which are small enough to be carried into the atmosphere, as is known to occur in the dispersal of other bacteria (Burrows et al. 2009). Second, the host density in relation to host-finding by the pathogen that leads to algal attack appears possibly to be an important requisite to the occurrence of an outbreak. A similar scenario has been observed for predatory Bdellovibrio spp., which share many characteristics with V. chlorellavorus (Varon and Shil 1968). The pathogen was not detected in the reactors until the algal host suspension culture reached a density of 1.0 (OD 750). The relationship between pathogen presence and the onset of an outbreak cannot be established based on the current limitations in knowledge about the temporal dynamics of host-pathogen interactions, and the mechanisms involved in host-finding and subsequent attack, e.g., pathogenicity, which could result in an outbreak and death of the algal host. It seems apparent that a latent period is required from the time of pathogen introduction to the point in time when it is detectable by qPCR amplification. In this study, the bacterial pathogen, $V$. chlorellavorus, was detectable at 7 to 9 days postinoculation of the reactor (Figs. 6 and S1), a timeframe that preceded the visually-detectable change in color from bright to dull green, followed by complete chlorosis, and algal cell death. The use of the qPCR amplification assay to conduct life history and pathogenicity studies under controlled laboratory conditions will aid in better understanding the temporal relationships between gene expression in relation to host-pathogen interactions, and to understand the molecular and cellular mechanisms that underlie the predatory behavior and specificity of the pathogenicity of the V. chlorellavorus to certain Chlorella species, over others. In addition, research will be needed to identify vulnerabilities in the bacterial life cycle based on new knowledge of mechanisms involved in host finding, pathogenesis, and virulence that may be targeted more specifically than is presently possible using general biocides, such as the application of BAC, reported here.

Acknowledgements The authors would like to express appreciation to Caitlin C. Brown and Noel Kitchen for their support and invaluable contributions with culture maintenance and qPCR assay design and validation, to undergraduates Cassandra Galves and Stephen Lee for laboratory assistance, and to the ARID raceway team. The first author would like to thank Drs. J.K. Brown and K. Ogden for guidance and mentoring throughout this study, leading to completion of his Master's Thesis.

Funding information Support for this research was provided from the Department of Energy Grant DE-EE0006269.

\section{Compliance with ethical standards}

Conflict of interest statement The authors declare they have no conflicts of interest.

\section{References}

Amann RI, Ludwig W, Schleifer KH (1995) Phylogenetic identification and in situ detection of individual microbial cells without cultivation. Microbiol Rev 59:143-169 
Amer L, Adhikari B, Pellegrino J (2011) Technoeconomic analysis of five microalgae-to-biofuels processes of varying complexity. Bioresour Technol 102:9350-9359

Armbruster DA, Pry T (2008) Limit of blank, limit of detection and limit of quantitation. Clin Biochem Rev 29:S49-S52

Benson DA, Cavanaugh M, Clark K, Karsch-Mizrachi I, Lipman DJ, Ostell J, Sayers EW (2013) GenBank. Nucleic Acids Res 41:D36D42

Burrows SM, Elbert W, Lawrence MG, Pöschl U (2009) Bacteria in the global atmosphere-part 1: review and synthesis of literature data for different ecosystems. Atmos Chem Phys 9:9263-9280

Camacho C, Coulouris G, Avagyan V, Ma N, Papadopoulos J, Bealer K, Madden TL (2009) BLAST+: architecture and applications. BMC Bioinformatics 10:421

Coder DM, Goff LJ (1986) The host range of the chlorellavorous bacterium ("Vampirovibrio chlorellavorus"). J Phycol 22:543-546

Coder DM, Starr MP (1978) Antagonistic association of the chlorellavorus bacterium ("Bdellovibrio" chlorellavorus) with Chlorella vulgaris. Curr Microbiol 1:59-64

Cole JR, Chai B, Farris RJ, Wang Q, Kulam SA, McGarrell DM, Garrity GM, Tiedje JM (2005) The ribosomal database project (RDP-II): sequences and tools for high-throughput rRNA analysis. Nucleic Acids Res 33:D294-D296

Crowe B, Attalah S, Agrawal S, Waller P, Ryan R, Van Wagenen J, Chavis A, Kyndt J, Kacira M, Ogden KL et al (2012) A comparison of Nannochloropsis salina growth performance in two outdoor pond designs: conventional raceways versus the arid pond with superior temperature management. Int J Chem Eng 2012:1-9

Daugbjerg N, Hansen G, Larsen J, Moestrup Ø (2000) Phylogeny of some of the major genera of dinoflagellates based on ultrastructure and partial LSU rDNA sequence data, including the erection of three new genera of unarmoured dinoflagellates. Phycologia 39:302-317

De Mendiburu F (2014) Agricolae: statistical procedures for agricultural research. R package version 1.1-6. https://CRAN.R-project.org/ package $=$ agricolae

Doyle J, Doyle JL (1990) Isolation of plant DNA from fresh tissue. FOCUS 12:13-15

Duffy T, Cura CI, Ramirez JC, Abate T, Cayo NM, Parrado R, Bello ZD, Velazquez E, Muñoz-Calderon A, Juiz NA, Basile J, Garcia L, Riarte A, Nasser JR, Ocampo SB, Yadon ZE, Torrico F, de Noya BA, Ribeiro I, Schijman AG (2013) Analytical performance of a multiplex real-time PCR assay using TaqMan probes for quantification of Trypanosoma cruzi satellite DNA in blood samples. PLoS Negl Trop Dis 7:e2000

Fry WE (1978) Quantification of general resistance of potato cultivars and fungicide effects for integrated control of potato late blight. Phytopathology 68:1650

Ganuza E, Sellers CE, Bennett BW, Lyons EM, Carney LT (2016) A novel treatment protects Chlorella at commercial scale from the predatory bacterium Vampirovibrio chlorellavorus. Front Microbiol 7:848

Green M, Sambrook J (2012) Molecular cloning: A laboratory manual (fourth edition): three volume set. Cold Spring Harbor Press, Cold Spring Harbor

Gromov BV, Mamkaeva KA (1972) Electron microscopic study of parasitism by Bdellovibrio chlorellavorus bacteria on cells of the green alga Chlorella vulgaris. Tsitologiia 14:256-260

Hou Y, Zhang H, Miranda L, Lin S (2010) Serious overestimation in quantitative PCR by circular (supercoiled) plasmid standard: microalgal pcna as the model gene. PLoS One 5:e9545

Houari A, Di Martino P (2007) Effect of chlorhexidine and benzalkonium chloride on bacterial biofilm formation. Lett Appl Microbiol 45: 652-656

Hu Q, Sommerfeld M, Jarvis E, Ghirardi M, Posewitz M, Seibert M, Darzins A (2008) Microalgal triacylglycerols as feedstocks for biofuel production: perspectives and advances. Plant J 54:621-639
Huesemann MH, Van Wagenen J, Miller T, Chavis A, Hobbs S, Crowe B (2013) A screening model to predict microalgae biomass growth in photobioreactors and raceway ponds. Biotechnol Bioeng 110:15831594

Huesemann M, Crowe B, Waller P, Chavis A, Hobbs S, Edmundson S, Wigmosta M (2016) A validated model to predict microalgae growth in outdoor pond cultures subjected to fluctuating light intensities and water temperatures. Algal Res 13:195-206

Jean MDS, Brignole F, Bringuier AF, Bauchet A, Feldmann G, Baudouin C (1999) Effects of benzalkonium chloride on growth and survival of Chang conjunctival cells. Invest Ophthalmol Vis Sci 40:619-630

Jorquera O, Kiperstok A, Sales EA, Embiruçu M, Ghirardi ML (2010) Comparative energy life-cycle analyses of microalgal biomass production in open ponds and photobioreactors. Bioresour Technol 101:1406-1413

Klindworth A, Pruesse E, Schweer T, Peplies J, Quast C, Horn M, Glöckner FO (2013) Evaluation of general 16S ribosomal RNA gene PCR primers for classical and next-generation sequencingbased diversity studies. Nucleic Acids Res 41:e1-e1

Lammers PJ, Huesemann M, Boeing W, Anderson DB, Arnold RG, Bai X, Bhole M, Brhanavan Y, Brown L, Brown J, Brown JK, Chisholm S, Meghan Downes C, Fulbright S, Ge Y, Holladay JE, Ketheesan B, Khopkar A, Koushik A, Laur P, Marrone BL, Mott JB, Nirmalakhandan N, Ogden KL, Parsons RL, Polle J, Ryan RD, Samocha T, Sayre RT, Seger M, Selvaratnam T, Sui R, Thomasson A, Unc A, van Voorhies W, Waller P, Yao Y, Olivares JA (2017) Review of the cultivation program within the National Alliance for Advanced Biofuels and Bioproducts. Algal Res 22:166-186

Lindow SE (1983) Estimating disease severity of single plants. Phytopathology 73:1576-1581

Malic S, Hill KE, Hayes A, Percival SL, Thomas DW, Williams DW (2009) Detection and identification of specific bacteria in wound biofilms using peptide nucleic acid fluorescent in situ hybridization (PNA FISH). Microbiology 155:2603-2611

Marchesi JR, Sato T, Weightman AJ, Martin TA, Fry JC, Hiom SJ, Wade WG (1998) Design and evaluation of useful bacterium-specific PCR primers that amplify genes coding for bacterial 16S rRNA. Appl Environ Microbiol 64:795-799

Matsuki T, Watanabe K, Tanaka R, Fukuda M, Oyaizu H (1999) Distribution of bifidobacterial species in human intestinal microflora examined with 16S rRNA-gene-targeted species-specific primers. Appl Environ Microbiol 65:4506-4512

McBride RC, Lopez S, Meenach C, Burnett M, Lee PA, Nohilly F, Behnke C (2014) Contamination management in low cost open algae ponds for biofuels production. Ind Biotechnol 10:221-227

Metting FB (1996) Biodiversity and application of microalgae. J Ind Microbiol Biotechnol 17:477-489

Park SH, Steichen SA, Li X, Ogden KL, Brown JK (2018) Association of Vampirovibrio chlorellavorus with decline and death of Chlorella sorokiniana in outdoor reactors. J Appl Phycol. https://doi.org/10. 1007/s10811-018-1633-9

Paulson DS (2002) Handbook of topical antimicrobials: industrial applications in consumer products and pharmaceuticals. CRC Press, Boca Raton

Pedroni PM, Lamenti G, Prosperi G, Ritorto L, Scolla G, Capuano F, Valdiserri M (2004) EniTecnologie R\&D project on microalgae biofixation of $\mathrm{CO}_{2}$ : outdoor comparative tests of biomass productivity using flue gas $\mathrm{CO}_{2}$ from a NGCC power plant. Enrgy Proced 2:1037-1042

R Core Team (2013) R: a language and environment for statistical computing. R Foundation for Statistical Computing, Vienna

Rinttila T, Kassinen A, Malinen E, Krogius L, Palva A (2004) Development of an extensive set of 16S rDNA-targeted primers for quantification of pathogenic and indigenous bacteria in faecal samples by real-time PCR. J Appl Microbiol 97:1166-1177 
Rippka R, Herdman M (1993) Pasteur culture collection of cyanobacterial strains in axenic culture, catalogue of strains 1992/1993. Pasteur Institute, Paris

Rozen S, Skaletsky H (2000) Primer3 on the WWW for general users and for biologist programmers. In: Misener S, Krawetz SA (eds) Bioinformatics methods and protocols. Meth Molec Biol 132. Humana Press, Totowa

Saiki RK, Gelfand DH, Stoffel S, Scharf SJ, Higuchi R, Horn GT, Mullis KB, Erlich HA (1988) Primer-directed enzymatic amplification of DNA with a thermostable DNA polymerase. Science 239:487-491

Simko I, Piepho H-P (2012) The area under the disease progress stairs: calculation, advantage, and application. Phytopathology 102:381-389

Soo RM, Skennerton CT, Sekiguchi Y, Imelfort M, Paech SJ, Dennis PG, Steen JA, Parks DH, Tyson GW, Hugenholtz P (2014) An expanded genomic representation of the phylum cyanobacteria. Genome Biol Evol 6:1031-1045

Soo RM, Woodcroft BJ, Parks DH, Tyson GW, Hugenholtz P (2015) Back from the dead; the curious tale of the predatory cyanobacterium Vampirovibrio chlorellavorus. PeerJ 3:e968

Stewart EJ (2012) Growing unculturable bacteria. J Bacteriol 194:41514160
Taylor S, Wakem M, Dijkman G, Alsarraj M, Nguyen M (2010) A practical approach to RT-qPCR - publishing data that conform to the MIQE guidelines. Methods 50:S1-S5

Varon M, Shil M (1968) Interaction of Bdellovibrio bacteriovorus and host bacteria. I Kinetic studies of attachment and invasion of Escherichia coli B by Bdellovibrio bacteriovorus. J Bacteriol 95: 744-753

Voth DE, Broederdorf LJ, Graham JG (2012) Bacterial Type IV secretion systems: versatile virulence machines. Future Microbiol 7:241-257

Wallden K, Rivera-Calzada A, Waksman G (2010) Microreview: Type IV secretion systems: versatility and diversity in function. Cell Microbiol 12:1203-1212

Waller P, Ryan R, Kacira M, Li P (2012) The algae raceway integrated design for optimal temperature management. Biomass Bioenergy 46:702-709

Weisburg WG, Barns SM, Pelletier DA, Lane DJ (1991) 16S ribosomal DNA amplification for phylogenetic study. J Bacteriol 173:697-703

Zhu F, Massana R, Not F, Marie D, Vaulot D (2005) Mapping of picoeucaryotes in marine ecosystems with quantitative PCR of the 18S rRNA gene. FEMS Microbiol Ecol 52:79-92 